\section{GAMBARAN MOTIVASI MAHASISWA KEPERAWATAN DALAM MENGHADAPI PELUANG KERJA KE LUAR NEGERI}

\author{
Overview of The Motivation of Nursing Students in Facing \\ Work Opportunities Abroad
}

\author{
Ni Putu Widianingsih, Ni Made Nopita Wati, Niken Ayu Merna Eka Sari \\ Sekolah Tinggi Ilmu Kesehatan Wira Medika Bali
}

\section{Riwayat artikel \\ Diajukan: 26 Juni 2020 \\ Diterima: 1 Oktober 2020}

\section{Penulis Korespondensi:}

- Ni Made Nopita Wati

- Sekolah Tinggi Ilmu Kesehatan Wira Medika Bali

e-mail:

ners.pita@gmail.com

\section{Kata Kunci:}

Motivasi, Peluang Kerja, Keperawatan

\begin{abstract}
Abstrak
Pendahuluan : Perawat mempunyai posisi penting dalam penyelenggaraan pelayanan kesehatan. Tenaga perawat dibutuhkan diseluruh fasilitas pelayanan kesehatan, baik di dalam maupun di luar negeri. Bekerja di luar negeri juga merupakan salah satu peluang bagi perawat Indonesia. Individu dengan motivasi kuat dapat terlihat dari kualitas perilaku yang ditampilkannya, baik dalam konteks belajar, bekerja, maupun dalam keseharianya. Tujuan : untuk mengetahui gambaran motivasi mahasiswa keperawatan dalam menghadapi peluang kerja ke luar negeri. Metode : Penelitian ini menggunakan metode deskriptif. Teknik yang digunakan Total Sampling dengan sampel 156 responden. Pengumpulan data menggunakan kuesioner dan telah di uji validitas serta reliabilitas sebelum digunakan. Hasil uji validitas memperlihatkan bahwa 30 item pernyataan didapatkan keseluruhan soal memiliki nilai r-hitung $(0,397-0,910)$ dan hasil uji reliabilitas dengan hasil reliabilitas yaitu 0.966 . Hasil : penelitian menunjukkan sebagian besar mahasiswa memiliki faktor motivasi intrinsik dan ekstrinsik yang tinggi. Faktor motivasi intrinsik sebanyak 59,0\% dan faktor minat ekstrinsik sebanyak $61,5 \%$. Kesimpulan : mahasiswa keperawatan, sebagian besar memiliki motivasi tinggi dalam menghadapi peluang kerja ke luar negeri. Hasil penelitian merupakan gambaran saja sehingga diharapkan dapat melakukan penelitian lebih lanjut mengenai hubungan motivasi dengan variabel yang ingin ditambahkan dan mengkaji lebih dalam mengenai motivasi mahasiswa untuk melanjutkan bekerja ke luar negeri.
\end{abstract}

\section{Abstract}

Background: Nurses have an important position in the delivery of health services. Nurses are needed in all health care facilities, both at home and abroad. Working abroad is also an opportunity for Indonesian nurses. Strong motivation of an individual will largely determine the quality of the behavior that is displayed, both in the context of learning, working, and in other lives. Objective : This study aims to determine the description of the motivation of nursing students in facing employment opportunities working abroad. Method: This research uses a descriptive method. The technique used is total sampling with a sample of 156 respondents. Data collection uses questionnaire. The result of the validity test showed that the 30 statemen item found that all questions had r-count value (0,397-0.910) and the reliability test result with the reliability result werw 0.966. Results : The results showed that most students had high intrinsic and extrinsic motivation factors, $59.0 \%$ intrinsic motivation factors and $61.5 \%$ extrinsic interest factors. Conclusion : Most of the Nursing students have high motivation in facing work opportunities abroad. The results of this study are only illustrated so that it is expected to conduct further research on the relationship of motivation with the variables to be added and examine more deeply the motivation of students to continue working abroad. 


\section{PENDAHULUAN}

Tenaga kesehatan, khususnya perawat memiliki posisi penting dalam penyelenggaraan pelayanan kesehatan. Perawat dibutuhkan diseluruh fasilitas pelayanan kesehatan, baik di dalam maupun di luar negeri. Bekerja di luar negeri juga merupakan salah satu peluang bagi perawat Indonesia (Kemenkes RI, 2015).

Perawat yang berasal dari Indonesia sudah sejak lama diminati oleh banyak rumah sakit maupun lembaga kesehatan di luar negeri. Hal ini terjadi karena perawat Indonesia memiliki ciri khas yang dikenal ramah serta suka bekerja keras. Beberapa negara yang menjadi sering menjadi tujuan untuk bekerja di luar negeri oleh perawat Indonesia diantaranya yaitu Malaysia, Brunei Darussalam, Hongkong, Taiwan, Arab Saudi, Korea Selatan dan Jepang. (Mam, 2016). Pengiriman tenaga perawat Indonesia ke Jepang juga diharapkan dapat membawa manfaat bagi kedua belah pihak. Perpindahan/migrasi tenaga medis dari Negaranegara berupah rendah ke Negara-negara berupah tinggi dapat meningkatkan efisiensi ekonomi (Arunanondchai, 2012). Bagi negara penerima, tenaga perawat asing yang masuk ke negara tersebut pada umumnya bermanfaat untuk mencukupi kekurangan tenaga medis domestik.

Peraturan mengenai penempatan perawat Indonesia ke Jepang diatur dalam Peraturan Badan Nasional Penempatan dan Perlindungan Tenaga Kerja Indonesia (BNP2TKI) Nomor: PENG.179/PENPPP/III/2016. Peraturan tersebut memuat tentang pelaksanaan penempatan calon TKI Kandidat Nurse (Kangoshi) dan calon TKI Kandidat Careworker (Kaigofukushishi) ke Jepang. Program Government to Government $(\mathrm{G}$ to G) dalam kerangka Indonesia Japan Economic Partnership Agreement (IJEPA) untuk penempatan tahun 2017 diantaranya calon TKI yang berminat bekerja ke Jepang harus memenuhi syarat : minimal berusia 21 dan telah lulus serendah-rendahnya D3 Keperawatan, serta memiliki surat Registrasi (STR) (Haryono, 2016). Persatuan Perawat Nasional Indonesia (PPNI) semenjak awal sudah menyampaikan nilai positif dari employment perawat Indonesia di Jepang karena setiap perawat memiliki hak untuk bekerja dimana pun di dunia ini, sesuai dengan kebijakan international concil of nurse (Shun, 2012).

Motivasi bekerja merupakan faktor utama yang dapat mempengaruhi perawat
Indonesia untuk bekerja ke luar negeri. Motivasi yang kuat dari individu akan berdampak pada kualitas perilaku yang ditampilkannya, baik dalam konteks belajar, bekerja, maupun dalam kehidupan sehari-harinya. Motivasi dikatakan sebagai suatu proses dimana adanya kebutuhan yang mendorong sesorang dalam melakukan kegiatan yang mengarah agar tercapai suatu tujuan (Mangkunegara, 2016).

Motivasi diungkap berdasarkan teori Johanes yaitu terdapat dua faktor yang mempengaruhi motivasi dimana faktor motivasi intrinsik dan faktor motivasi ekstrinsik. Faktor motivasi intrinsik adalah faktor yang timbul dari dalam individu yaitu sikap, persepsi, prestasi, bakat, jenis kelamin, dan harapan bekerja. Faktor motivasi ekstrinsik adalah faktor motivasi yang timbul karena pengaruh dari luar individu yaitu latar belakang sosial ekonomi, motivasi orang tua, informasi, dan lingkungan (Walgito, 2012).

\section{METODE PENELITIAN}

Jenis penelitian ini merupakan penelitian deskriptif kuantitatif yang bertujuan untuk mengetahui Gambaran Motivasi Mahasiswa Keperawatan Dalam Menghadapi Peluang Kerja Ke Luar Negeri. Pendekatan yang digunakan yaitu cross sectional. Jumlah sampel sebanyak 156 orang dengan teknik sampel Non Probability Sampling yaitu dengan metode Total Sampling dengan 30 pertanyaan sebelum pelaksanaan kuesioner telah dilakukan uji validitas dan uji realibitas dan berdasarkan uji analisis 30 pertanyaan dinyatakan valid dan realibel, uji analisa data digunakan univariat. Penelitian ini menggunakan etika penelitian berupa anonym, kerahasiaan, berbuat baik serta tidak ada unsur paksaan bagi responden untuk menjadi subyek pada penelitian ini

\section{HASIL DAN PEMBAHASAN}

\section{HASIL}

\section{Karakteristik Responden}

Tabel 4.1

Distribusi karakteristik responden berdasarkan jenis kelamin di STIKes Wira Medika Bali

\begin{tabular}{lcc}
\hline Jenis Kelamin & Frekuensi & Presentase \% \\
\hline Laki-laki & 26 & $16,7 \%$ \\
Perempuan & 130 & $83,3 \%$ \\
\hline Total & $\mathbf{1 5 6}$ & $\mathbf{1 0 0 \%}$ \\
\hline
\end{tabular}


Berdasarkan tabel 4.1 diketahui bahwa hamper seluruh responden berjenis kelamin perempuan yaitu sebanyak $83,3 \%$.

Tabel 4.2

Distribusi karakteristik responden berdasarkan usia di STIKes Wira Medika Bali

\begin{tabular}{lcc}
\hline Usia & Frekuensi & $\begin{array}{c}\text { Presentase } \\
\text { \% }\end{array}$ \\
\hline 21 Tahun & 69 & $46,8 \%$ \\
22 Tahun & 87 & $53,2 \%$ \\
\hline Total & $\mathbf{1 5 6}$ & $\mathbf{1 0 0 \%}$ \\
\hline
\end{tabular}

Berdasarkan tabel 4.2 diketahui bahwa sebagian besar responden berusia berusia 22 Tahun sebanyak $53,2 \%$.

\section{Motivasi Mahasiswa Keperawatan} Dalam Menghadapi Peluang Kerja ke Luar Negeri

Tabel 4.3

Distribusi Faktor Motivasi Intrinsik Mahasiswa Keperawatan Dalam Menghadapi Peluang Kerja Ke Luar Negeri di STIKes Wira Medika Bali

\begin{tabular}{|c|c|c|}
\hline $\begin{array}{l}\text { Faktor Motivasi } \\
\text { Intrinsik }\end{array}$ & Frekuensi & Presentase \% \\
\hline $\begin{array}{l}\text { Tinggi } \\
(91 \%-100 \%)\end{array}$ & 92 & $59,0 \%$ \\
\hline $\begin{array}{l}\text { Sedang } \\
(61 \%-90 \%)\end{array}$ & 56 & $35,9 \%$ \\
\hline $\begin{array}{l}\text { Rendah } \\
(30 \%-60 \%)\end{array}$ & 8 & $5,1 \%$ \\
\hline Total & 156 & $100 \%$ \\
\hline
\end{tabular}

Berdasarkan tabel 4.2 diketahui bahwa hamper seluruh mahasiswa memiliki faktor motivasi intrinsik yang tinggi dalam menghadapi peluang kerja ke luar negeri di STIKes Wira Medika Bali yaitu sebanyak $59,0 \%$.

Tabel 4.4

Distribusi Faktor Motivasi Ekstrinsik Mahasiswa Keperawatan Dalam Menghadapi Peluang Kerja Ke Luar Negeri di STIKes Wira Medika Bali

\begin{tabular}{lcc}
\hline $\begin{array}{l}\text { Faktor Motivasi } \\
\text { Ekstrinsik }\end{array}$ & Frekuensi & Presentase \% \\
\hline $\begin{array}{l}\text { Tinggi } \\
(91 \%-100 \%)\end{array}$ & 96 & $61,5 \%$ \\
$\begin{array}{l}\text { Sedang } \\
(61 \%-90 \%)\end{array}$ & 52 & $33,3 \%$ \\
$\begin{array}{l}\text { Rendah } \\
(\mathbf{3 0 \% - 6 0 \% )}\end{array}$ & 8 & $5,1 \%$ \\
\hline Total & $\mathbf{1 5 6}$ & $\mathbf{1 0 0 \%}$ \\
\hline
\end{tabular}

Berdasarkan tabel 4.4 diketahui bahwa hamper seluruh mahasiswa memiliki faktor motivasi ekstrinsik yang tinggi dalam menghadapi peluang kerja ke luar negeri di STIKes Wira Medika Bali yaitu sebanyak $61,5 \%$.

\section{PEMBAHASAN}

Hasil penelitian menunjukkan bahwa dari 156 responden sebagian besar responden berjenis kelamin perempuan yaitu sebanyak 130 orang $(83,3 \%)$. Hasil penelitian ini sejalan dengan penelitian yang dilakukan oleh (Wicaksono, 2014). Hasil penelitian ini menunjukkan bahwa jenis kelamin mahasiswa paling banyak adalah perempuan dengan persentase $81,4 \%$ di Poltekkes Kemenkes Yogyakarta. Penelitian yang dilakukan oleh (Heris, 2012), juga menunjukan sebagian besar jenis kelamin mahasiswa paling banyak adalah perempuan dengan persentase $86,4 \%$ di Stikes Yarsis. Penelitian yang dilakukan oleh (Fauzi, 2017), juga menunjukkan bahwa jenis kelamin perawat paling banyak adalah perempuan dengan persentase $69,3 \%$ di STIKes Dharma Husada Bandung Jl. Terusan Jakarta 75 Bandung. Berdasarkan hasil penelitian dan penelitian sebelumnya yang menunjukan bahwa jenis kelamin terkait dengan motivasi dalam menghadapi peluang kerja ke luar negeri sebagian besar perempuan.

Jenis kelamin berperan dalam menentukan motivasi mahasiswa, antara lakilaki dan perempuan memiliki pola pikir yang berbeda untuk menentukan motivasinya. Lakilaki lebih suka melihat sesuatu yang mudah dan memiliki kemampuan motorik yang jauh lebih kuat dibandingkan perempuan. Perempuan lebih sering mengandalkan perasaan karena otak perempuan lebih bisa mengaitkan memori dan keadaan sosial. Perempuan lebih sering menggunakan otak kanannya dimana hal tersebut yang menjadi alasan perempuan lebih mampu melihat dari berbagai sudut pandang dan menarik kesimpulan. Motivasi mahasiswa lakilaki maupun perempuan tentunya tidak dapat disangkal lagi bahwa turut mendorong dalam menghadapi peluang kerja ke luar negeri (Walgito, 2012).

Menurut peneliti, mayoritas responden yang memiliki motivasi tinggi adalah perempuan karena jumlah populasi perempuan lebih banyak dibandingkan dengan laki-laki. Profesi keperawatan banyak digeluti oleh perempuan disebabkan karena sikap dasar perempuan yang identik dengan sikap yang 
ramah, sabar, lembut dan lebih perhatian dibandingkan laki-laki.

Pada penelitian yang dilakukan di Sekolah Tinggi Ilmu Kesehatan Wira Medika Bali terkait dengan motivasi mahasiswa keperawatan dalam menghadapi peluang kerja ke luar negeri dilihat dari umur, menunjukkan bahwa dari 156 responden, sebagian besar responden berumur 22 Tahun sebanyak 87 orang $(53,2 \%)$. Hasil penelitian ini sejalan dengan penelitian yang dilakukan oleh Wicaksono (2014), hasil penelitian ini menunjukkan bahwa umur mahasiswa paling banyak adalah berumur 21 Tahun sebanyak 96 orang dengan persentase 81,4\% di Poltekkes Kemenkes Yogyakarta. Penelitian yang dilakukan oleh (Heris, 2012), menunjukan sebagian besar umur mahasiswa paling banyak adalah 21 Tahun dengan persentase 82,6\% di Stikes Yarsis. Penelitian yang dilakukan oleh (Fauzi, 2017), hasil penelitian ini menunjukkan bahwa umur perawat paling banyak adalah 24 Tahun dengan persentase 73,1\% di STIKes Dharma Husada Bandung Jl. Terusan Jakarta 75 Bandung. Berdasarkan hasil penelitian dan penelitian sebelumnya menunjukan umur terkait dengan motivasi dalam menghadapi peluang kerja ke luar negeri sebagian besar berumur lebih muda.

Umur lebih muda cenderung lebih memiliki motivasi yang tinggi dibandingkan usia yang lebih tua dengan contoh seorang perempuan berusia dini yang mengalami suatu permasalahan, lebih sering mengeluh kalau dirinya merasa cemas, hal ini terjadi kemungkinan karena umur lebih muda belum mengalami pengalaman untuk menghadapinya. Umur berkaitan erat dengan tingkat kedewasaan teknis dalam menjalankan tugas-tugas maupun kedewasaan psikologis. Motivasi yang tinggi lebih mudah dialami oleh seseorang yang mempunyai usia lebih muda dibandingkan individu dengan usia yang lebih tua (Kaplan \& Sadock, 2010) Menurut hasil pengamatan yang dilakukan peneliti saat bertanya dengan responden dalam menghdapi peluang kerja ke luar negeri mengatakan bahwa dirinya merasa termotivasi ketika memikirkan untuk bekerja ke luar negeri dan juga sudah siap menghadapi peluang kerja ke luar negeri.

Menurut asumsi peneliti karakteristik responden berdasarkan umur di atas mempunyai pengaruh yang cukup besar terhadap motivasi mahasiswa karena umur mahasiswa yang muda adalah masa yang sangat labil, cepat emosi dan mudah cemas. Sedangkan umur seseorang yang lebih tua lebih mampu mengendalikan emosi, lebih bijak dalam mengambil suatu keputusan, berfikir secara rasional dan lebih toleransi dibandingkan dengan umur yang lebih muda. Mahasiswa yang mengalami motivasi rendah lebih cenderung terjadi pada umur yang lebih muda, mengingat dari segi psikologi dan sosial emosionalnya belum begitu matang untuk menerima cobaan yang terjadi pada dirinya

Hasil penelitian diketahui bahwa dari 156 responden, sebagian besar memiliki faktor motivasi intrinsik yang tinggi yaitu sebanyak 92 orang $(59,0 \%)$, hanya 8 orang $(5,1 \%)$ yang memiliki faktor motivasi intrinsik yang rendah. Faktor motivasi intrinsik dilihat dari aspek sikap, persepsi, prestasi belajar dan harapan bekerja. Sikap mahasiswa keperawatan merupakan hal yang penting karena perawat harus bersikap dengan baik terhadap diri sendiri maupun orang lain dimana tercermin dalam pengambilan keputusan apakah baik untuk diri sendiri maupun orang lain. Hal ini mengacu pada pernyataan nomor 1 yaitu "Setelah menyelesaikan pendidikan S1 Keperawatan saya ingin melanjutkan bekerja ke luar negeri”, dari 156 responden sebagian besar responden menjawab sangat setuju sebanyak 98 orang $(62,8 \%)$. Hasil ini menjawab bahwa mahasiswa lebih dominan ingin untuk melanjutkan bekerja ke luar negeri.

Persepsi mengacu pada pernyataan nomor 3 yaitu "Bekerja di luar negeri lebih terjamin masa depannya sehingga saya tertarik untuk bekerja ke luar negeri", dari 156 responden sebagian besar responden menjawab sangat setuju sebanyak 97 orang $(62,2 \%)$, dari hasil ini terlihat bahwa mahasiswa lebih dominan mempersepsikan bekerja diluar negeri akan terjamin masa depannya.

Prestasi belajar mengacu pada pernyataan nomor 5 yaitu "Keterampilan yang saya miliki sudah lumayan sehingga saya ingin melanjutkan bekerja ke luar negeri", dari 156 responden sebagian besar responden menjawab sangat setuju sebanyak 84 orang $(53,8 \%)$, dari hasil ini dapat terlihat bahwa sebagian besar mahasiswa memiliki kesadaran untuk keterampilannya dan merasa perlu untuk melanjutkan bekerja ke luar negeri. Hal ini sejalan dengan teori (Dermawan, 2013), bahwa sistem pendidikan tenaga keperawatan diselenggarakan dengan sistem terbuka yang terus berkembang secara terarah, bertahap dan terkendali sehingga mencapai jenjang dan program pendidikan keperawatan yang paling tinggi. 
Harapan bekerja mengacu pada pernyataan nomor 4 yaitu "Saya ingin melanjutkan bekerja ke luar negeri karena dengan bekerja ke luar negeri mempunyai peluang lebih besar untuk memperoleh kedudukan yang lebih baik di tempat kerja", dari 156 responden sebagian besar responden menjawab sangat setuju sebanyak 102 orang $(65,4 \%)$, dari hasil ini terlihat bahwa lebih dominan mahasiswa memiliki harapan bekerja yang tinggi untuk memperoleh kedudukan yang lebih baik sehingga ingin melanjutkan bekerja ke luar negeri. Kedudukan yang baik dapat diperoleh dengan meningkatkan jenjang pendidikan sehingga pekerjaan yang didapat akan sesuai dengan lingkup jenjang pendidikan tersebut. Hal ini sejalan dengan teori (Dermawan, 2013), bahwa perawat teregister mempunyai berbagai lingkup atau area pekerjaan salah satunya adalah Hospital Nurse (Perawat Rumah Sakit).

Hasil penelitian ini secara keseluruhan dari faktor motivasi intrinsik disebabkan karena mahasiswa sudah berada dalam lingkup dunia keperawatan dimana mahasiswa belajar mengenai ilmu keperawatan serta mengetahui informasi mengenai peluang kerja dalam bidang keperawatan. Hal ini didukung dengan adanya teori dalam (Walgito, 2012), bahwa motivasi dapat timbul dari situasi belajar dimana seseorang yang belum pernah mendengar tentang bidang perawatan maka tidak akan menaruh motivasi terhadap perawatan. Namun setelah mendengar dan melihat berbagai hal terkait perawatan maka motivasi tersebut akan timbul.

Hasil penelitian di atas sejalan dengan hasil penelitian dari (Wicaksono, 2014), didapatkan bahwa dari 118 responden yang paling banyak memiliki motivasi intrinsik tinggi untuk bekerja ke luar negeri adalah sebanyak 75 responden (63,6\%). Penelitian ini sejalan dengan hasil penelitian dari (Fauzi, 2017), didapatkan bahwa dari 180 responden yang paling banyak memiliki motivasi intrinsik tinggi untuk bekerja ke luar negeri adalah sebanyak 113 responden $(62,8 \%)$. Penelitian ini sejalan dengan hasil penelitian dari (Heris, 2012), didapatkan bahwa dari 184 responden yang paling banyak memiliki motivasi intrinsik tinggi untuk bekerja ke luar negeri adalah sebanyak 91 responden $(51,9 \%)$.

Peneliti berasumsi bahwa mahasiswa keperawatan yang sudah belajar selama delapan semester tentunya akan mengalami hal tersebut, motivasi timbul dari sesuatu yang diketahui dan dipupuk melalui proses belajar. Menurut peneliti, mahasiswa dalam menentukan motivasinya untuk melanjutkan bekerja ke luar negeri dilihat dari faktor motivasi ekstrinsik termasuk dalam kategori tinggi dikarenakan mayoritas mahasiswa sudah memiliki keinginan untuk melanjutkan bekerja ke luar negeri.

Hasil penelitian diketahui bahwa dari 156 responden, sebagian besar memiliki faktor motivasi ekstrinsik yang tinggi yaitu sebanyak 96 orang $(61,5 \%)$. Hal ini sejalan dengan hasil penelitian yang dilakukan oleh (Fauzi, 2017), tentang "Gambaran Motivasi Mahasiswa Perawat Indonesia Untuk Bekerja Ke Jepang Di Japan Foundation Jakarta Selatan". Hasil penelitian tersebut menunjukkan bahwa mahasiswa dengan kategori minat tinggi lebih banyak daripada kategori minat rendah yaitu sebanyak 123 orang $(68,3 \%)$.

Faktor motivasi ekstrinsik dilihat dari aspek latar belakang sosial ekonomi, motivasi orang tua, informasi dan lingkungan dimana latar belakang sosial ekonomi akan mempengaruhi proses kelancaran mahasiswa dalam segi biaya. Hal ini mengacu pada pernyataan nomor 21 yaitu "Saya tidak ingin melanjutkan bekerja ke luar negeri karena tidak ada yang membiayai saya", dari 156 responden sebagian besar responden menjawab kurang setuju sebanyak 84 orang (44\%), dari hasil ini dapat terlihat bahwa mahasiswa lebih dominan ingin melanjutkan bekerja ke luar negeri meskipun bermasalah pada biaya. Pada pernyataan lainnya yang sebagian besar responden menjawab sangat setuju sebanyak 97 orang $(62,2 \%)$ mengenai motivasi orang tua yang mengacu pada pernyataan nomor 18 yaitu "Saya tertarik untuk melanjutkan bekerja ke luar negeri karena dukungan dari orang tua saya". Jika poin pernyataan ini dihubungkan dengan latar belakang sosial ekonomi maka jelas hal ini menyebabkan sebagian mahasiswa menyatakan bahwa biaya yang ditanggung selama masa pendidikan bekerja ke luar negeri dapat mempengaruhi bahkan menghambat mahasiswa untuk mengikuti pendidikan bekerja ke luar negeri, dari hal ini terlihat bahwa dukungan orang tua akan sangat mempengaruhi motivasi mahasiswa dalam melanjutkan bekerja ke luar negeri. Informasi pada faktor motivasi ekstrinsik sebesar 55\% yang mengacu pada pernyataan nomor 19 yaitu "Saya tertarik untuk melanjutkan bekerja ke luar negeri karena saat ini dibutuhkan banyak tenaga perawat", dari 156 
responden sebagian besar responden menjawab sangat setuju sebanyak 108 orang. Hal ini dikarenakan mahasiswa sudah memperoleh informasi yang cukup dari pengalamanpengalaman yang sudah didapat selama proses pembelajaran. Hasil ini menjawab bahwa mayoritas mahasiswa mengerti tentang kebutuhan masyarakat yang memerlukan tenaga perawat sehingga tertarik untuk melanjutkan bekerja ke luar negeri. Lingkungan mengacu pada pernyataan nomor 20 yaitu "Rumah sakit di luar negeri membutuhkan tenaga terampil dengan pengetahuan luas, sehingga saya menumbuhkan motivasi saya untuk melanjutkan bekerja ke luar negeri”, dari 156 responden sebagian besar responden menjawab sangat setuju sebanyak 111 orang $(71,2 \%)$ karena Rumah sakit merupakan lingkup atau area pekerjaan terbesar dari seluruh perawat. Hasil ini sesuai dengan teori (Dermawan, 2013), bahwa perawat teregister mempunyai berbagai lingkup atau area pekerjaan sesuai dengan jenjang pendidikan yang ditempuh, hal ini menjawab bahwa mayoritas mahasiswa sadar akan pentingnya keterampilan dan pengetahuan luas dimana hal tersebut akan membantu dalam mendapatkan lingkungan pekerjaan yang baik sehingga tertarik untuk melanjutkan bekerja ke luar negeri.

Hasil penelitian di atas sejalan dengan hasil penelitian dari (Wicaksono, 2014), didapatkan bahwa dari 118 responden yang paling banyak memiliki motivasi ekstrinsik tinggi untuk bekerja ke luar negeri adalah sebanyak 86 responden $(72,9 \%)$. Penelitian ini sejalan dengan hasil penelitian dari (Fauzi, 2017), didapatkan bahwa dari 180 responden yang paling banyak memiliki motivasi ekstrinsik tinggi untuk bekerja ke luar negeri adalah sebanyak 108 responden $(60,0 \%)$. Penelitian ini sejalan dengan hasil penelitian dari (Heris, 2012), didapatkan bahwa dari 184 responden yang paling banyak memiliki motivasi ekstrinsik tinggi untuk bekerja ke luar negeri adalah sebanyak 93 responden $(51,7 \%)$.

Menurut peneliti, mahasiswa dalam menentukan motivasinya untuk melanjutkan bekerja ke luar negeri dilihat dari faktor motivasi ekstrinsik termasuk dalam kategori tinggi dikarenakan mayoritas mahasiswa sudah memperoleh dukungan orang tua, informasi yang cukup, lingkungan yang mendukung serta faktor sosial ekonomi yang memadai dilihat dari hasil pada faktor dalam motivasi ekstrinsik.

\section{KESIMPULAN}

Berdasarkan hasil penelitian dan pembahasan tentang Gambaran Motivasi Mahasiswa Keperawatan Untuk Melanjutkan bekerja ke luar negeri di STIKes Wira Medika Bali, dapat disimpulkan karakteristik responden dalam penelitian ini sebagian besar adalah berjenis kelamin perempuan yaitu sebanyak 130 orang $(83,3 \%)$ dan sebagian besar responden berusia 22 tahun sebanyak 87 orang $(53,2 \%)$. Sebagian besar responden memiliki faktor motivasi intrinsik yang tinggi yaitu sebanyak 92 orang $(59,0 \%)$. Sebagian besar responden memiliki faktor motivasi ekstrinsik yang tinggi yaitu sebanyak 96 orang (61,5\%). Diharapkan penelitian selanjutnya dapat meneliti lebih lanjut mengenai hubungan motivasi dengan variabel lain dan mengkaji lebih dalam mengenai motivasi mahasiswa untuk melanjutkan bekerja ke luar negeri

\section{DAFTAR PUSTAKA}

Arunanondchai. (2012). Pengaruh Profesionalisme, Pelatihan Dan Motivasi Terhadap Kinerja Nurse Dan Caregiver Indonesia.

Dermawan, D. (2013). Pengantar Keperawatan Profesional. Yogyakarta: Gosyen Publishing.

Fauzi. (2017). Gambaran Motivasi Perawat Indonesia Untuk Bekerja Ke Jepang Di Japan Foundation Jakarta Selatan Tahun $2017 . \quad$ Diakses dari http://journal.unusa.ac.id. Diunduh pada tanggal 02 Oktober 2019.

Haryono. (2016). BNP2TKI. Pengumuman Pendaftaran Calon Tki Asisten Untuk Jabatan Asisten Nurse (Asisten Kangoshi) Dan Calon Tki Asisten Careworker (Asisten Kaigofukushishi) Ke Jepang Program G to G Untuk Penempatan Tahun 2016. Diakses dari http://www.bnp2tk.

Heris. (2012). Gambaran Motivasi Mahasiswa STIKes Yarsis Dalam Menghadapi Peluang Kerja Di Kancah Internasional. Diakses dari http://journal.unusa.ac.id. Diunduh pada tanggal 02 Oktober.

Kaplan \& Sadock, G. J. 2010. (2010). Sinopsis Psikiatri Ilmu Pengetahuan Perilaku Psikiatri Klinis. Tangerang: BINARUPA AKSARA.

Mam. (2016). Lembaga Kajian Perawat 
Indonesia Perlindungan Kerja. Diunduh dari https://books.google.com. Diakses pada tanggal 4 Desember 2019.

Mangkunegara. (2016). Manajemen Sumber Daya Manusia dan Perusahaan. Bandung. PT. Remaja Rosda Karya.

RI, K. (2015). Rencana Strategis Kementerian Kesehatan Tahun 2015-2019. Jakarta: Kementerian Kesehatan RI;2015.

Shun. (2012). Badan Nasional Penempatan dan Perlindungan Tenaga Kerja Indonesia (BNP2TKI). Diakses dari http://www.bnp2tki.go.id. Diunduh pada tanggal 4 Desember 2019.

Walgito. (2012). Pengantar Psikologi Umum. Yogyakarta: Penerbit Andi.

Wicaksono. (2014). Gambaran Motivasi Untuk Bekerja Ke Luar Negeri Pada Mahasiswa Prodi D-III Keperawatan Poltekkes Kemenkes Yogyakarta. Diakses dari http://journal.unusa.ac.id. Diunduh pada tanggal 02 Oktober 2019. 